process performed to ensure that the final product meets design specifications as well as in-service performance of the pavement [2]. The pavement dimensioning procedure can be effected with the CEBTP [4] approach or using softwares such as Ecoroute and and Alizé, which compares the pavement material characteristics to the traffic demands. Consequently obtaining these characteristics have been the subject of debate among various stakeholders. The objective of this work is to characterize the lateritic materials and obtain a correlation between the modulus of elasticity and the Californian bearing ratio around the Mbu-Baforchu area in a bid to dimension a second access highway to the city of Bamenda.

\section{Geotechnical properties}

The study area is located between Santa and Bali subdivisions of Mezam Division of the North West Region of Cameroon. The starting point of the new road stretch is located at Akum which corresponds to the geographical coordinates of latitude $5^{\circ} 47^{\prime} 30^{\prime \prime} \mathrm{N}$ and of longitude $10^{\circ} 11^{\prime} 05^{\prime \prime} \mathrm{E}$ with an average elevation of $1788 \mathrm{~m}$. While the end of the road stretch is located in the suburb of Bali at a latitude of $5^{\circ} 52^{\prime} 59^{\prime \prime} \mathrm{N}$ of longitude $10^{\circ} 01^{\prime} 00^{\prime \prime} \mathrm{E}$ having an altitude of $1358 \mathrm{~m}$. Figure 1 shows the location map of the study area.

The meteorological records of Santa subdivision was obtained from the North West Regional Transport Delegation. The area is characterized by an average temperature
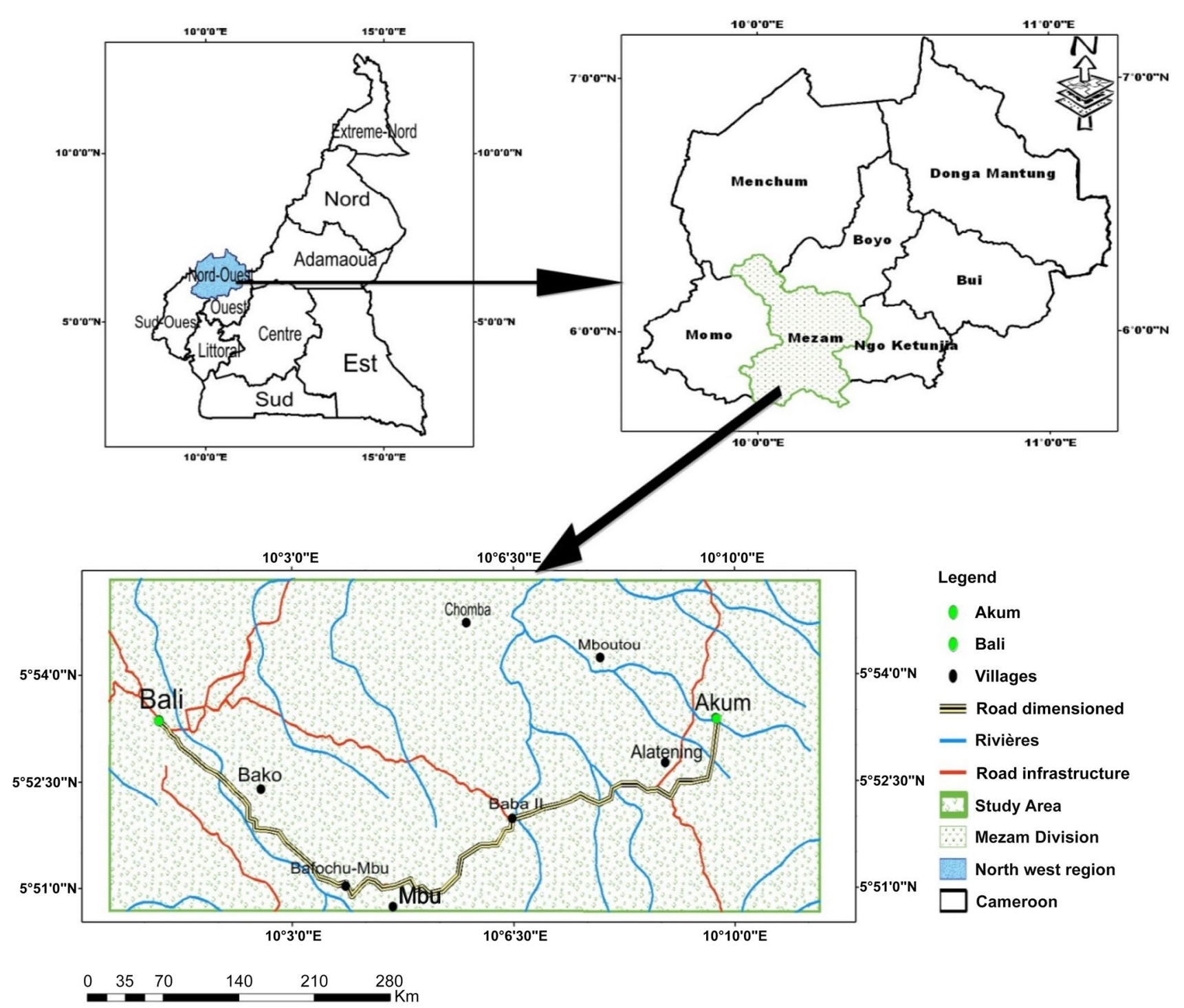

Fig. 1 Location map of the study area based on the 1/50000 Bafoussam 3c map. Source: National Geographical Institute-Paris [9] 
Table 1 Average monthly precipitation and temperature of the Santa district. Source: Regional delegation of Northwest Transportation in Amawa et al. [1]

\begin{tabular}{lllllllllllll}
\hline Month & January & February & March & April & May & June & July & August & September & October & November & December \\
\hline Rainfall $(\mathrm{mm})$ & 10 & 20 & 90 & 21 & 192 & 310 & 402 & 440 & 415 & 230 & 17 & 50 \\
Temperature $\left({ }^{\circ} \mathrm{C}\right)$ & 22.1 & 22.7 & 23.0 & 22.6 & 21.8 & 20.9 & 20.1 & 20.1 & 20.5 & 20.8 & 21.5 & 21.7 \\
\hline
\end{tabular}

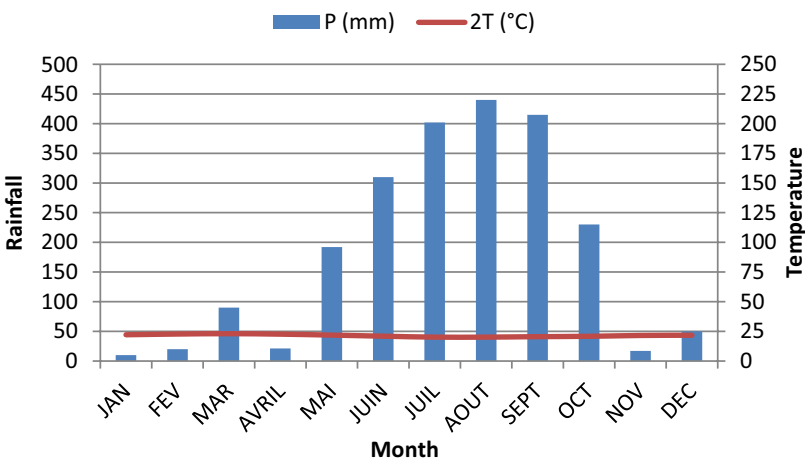

Fig. 2 Ombrothermic Diagram of Santa sub-division (period 20012011)

of $21.5^{\circ} \mathrm{C}$ and an annual average rainfall of $2197 \mathrm{~mm}$. Table 1 gives the climate data (temperature and precipitation), while Fig. 2 gives the Ombrothermal diagram of the Santa sub division respectively.

The study area belongs to the Western Highlands of Cameroon and more specifically to the Bamenda Mountains. It is located within the Mbu-Santa caldera and is characterized by a hilly landscape. The soil formations in the study area belong to the group of ferrallitic soils like most of the soils of the Western Highlands of Cameroon. These soils were formed by the alteration of volcanic rocks of trachyte and ignimbrite origin set up 13.21 and 20.6 MYears ago. Their mineralogy consists of alkali feldspar, quartz, plagioclase, clinopyroxene, biotite and oxides [10]. The primary minerals were mainly transformed by the process of laterisation into kaolinite. Volcanological studies carried out by Gountié et al. [6] make it possible to describe the geology of the study area from the geological map of the Mbu-Santa caldera (Fig. 3) and the stratigraphic diagram of the geological formations are shown in Fig. 4.

\section{Materials and methods}

\subsection{Field and laboratory work}

Remolded samples were collected from burrow pits as well as from the sub-grade. Three of the burrow pits were located close to the road, while subgrade materials were collected along the road stretch. Seven (07) representative

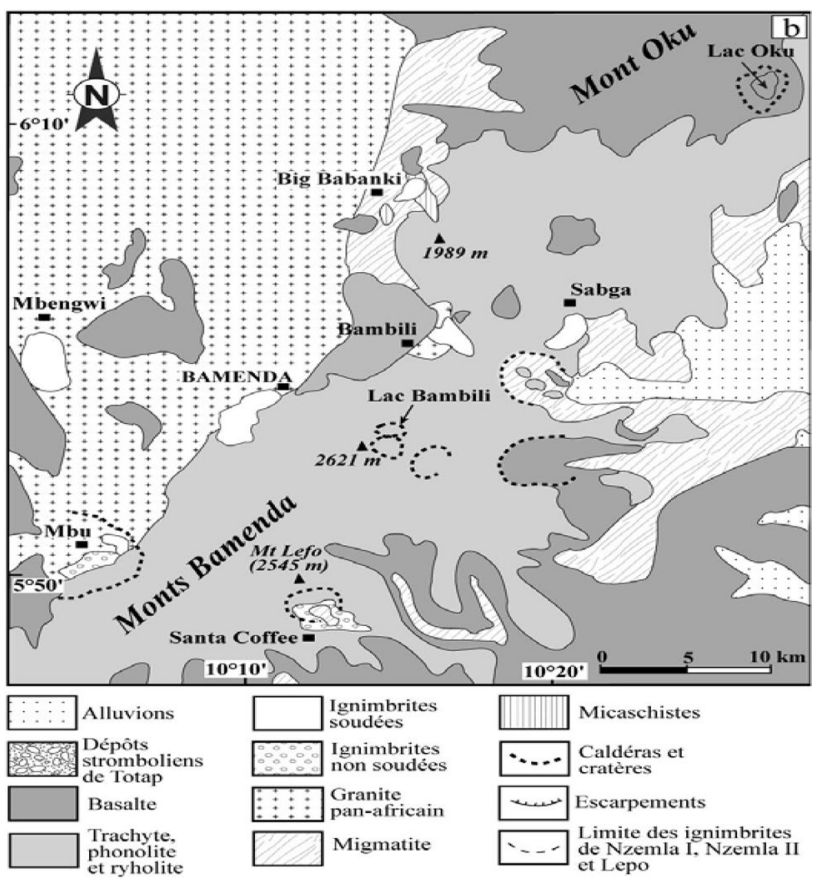

Fig. 3 Geological map of the Bamenda Mountains. Source: Kamgang et al. [10] and modified by Gountié et al. [6]

samples were taken from the burrow pits while nine (09) samples were collected from the subgrade over a distance of $10 \mathrm{~km}$ each. These were packaged in plastic bags of approximately $40 \mathrm{~kg}$ each and transported by a pick-up vehicle for the purpose of determining geotechnical characteristics in the laboratory. The laboratory analysis carried out were particle size analysis done in accordance with the NFP 94-056 [15]; the Atterberg limits done in accordance with the NFP 94-051 [14] and mechanical characteristics. The mechanical characteristics tests consists of the modified Proctor test carried out in accordance with the NFP 94-093 [16], CBR test carried out in accordance with the NFP 94078 [13] and finally simple compression test. The compression test was performed on the CBR equipment with the specimen sandwiched between two metal discs of similar circumference. The plunger transmits a vertical load through a steel ball onto the top disc and the specimen is sheared along the vertical axis at the same rate of shearing as in the CBR testing. The static elastic modulus obtained allows us to find the modulus elasticity (Edyn). 


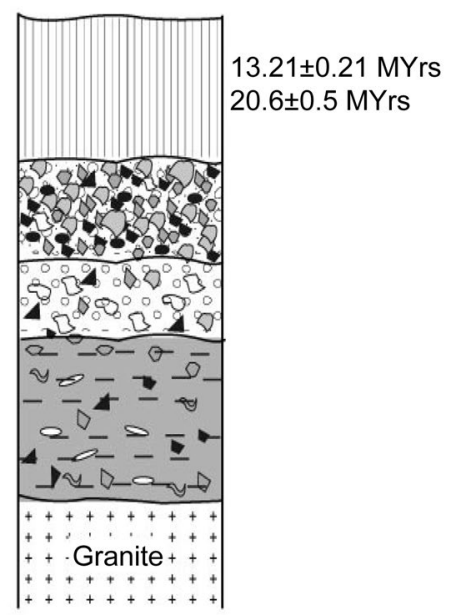

Santa-Mbu caldeira (b)

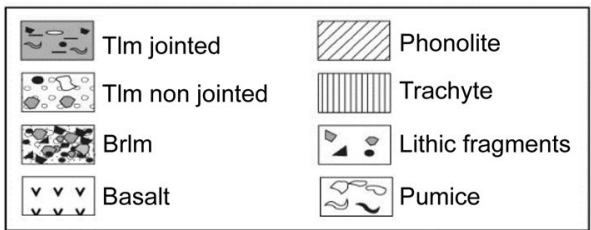

Fig. 4 Stratigraphic diagram of the geological formations of SantaMbu. Source: Kamgang et al. [10] and modified by Gountié et al. [6]

This parameter is calculated by the expression $\mathrm{E}_{\text {dyn }}=3 \mathrm{E}_{\text {stat }}$ with $E_{s t a t}=R \times L / \Delta L$ where $E_{\text {stat }}$ is the static modulus of elasticity, $R$ the compressive strength of the material, $\Delta \mathrm{L}$ the variation of the specimen length.

\subsection{CEBTP method for tropical countries}

This method was established in 1972 and is based on the design guide by CEBTP (Centre Expérimental du Bâtiment et de Travaux Publics). This guide was established by a host of engineers from the French Public Works Laboratories in collaboration with CEBTP. The method takes into consideration pavements with no stiffened layers and multilayered pavements. In the first case it requires the CBR of the subgrade and the traffic loadings to dimension the pavement. While for pavements comprising multiple layers with various stiffness parameters, the design which is required to withstand shear within the sub-grade must be carried out by a theoretical analysis requiring the determination of the effective tensile stresses developed within the layers. The CEBTP method therefore utilizes two tables comprising, Table 2 which gives the CBR values as a function of the soil sub-grade classes permitting the determination of the required thicknesses of the sub-base, base and surface layers. Also Table 3 which specifies the traffic loading and it is
Table 2 CBR values as a function of subgrade soil classes

\begin{tabular}{ll}
\hline Soil classes & CBR values \\
\hline S1 & CBR $<5$ \\
S2 & $5<C B R<10$ \\
S3 & $10<C B R<15$ \\
S4 & $15<C B R<30$ \\
S5 & CBR $>30$ \\
\hline
\end{tabular}

subdivided into five classes expressed in cumulative number of passes of one axle which is equivalent to 13 tons.

\subsection{French pavement design method: use of Alizée-LCPC software}

The Alizé software (also called ALIZE-LCPC) was developed in 1965 by LCPC and SETRA. This was put in place to facilitate as much as possible the implementation of the rational design method. This software enables the determination of stresses resulting from various traffic loadings in the different pavement layers as well as the deflection on the riding course, in principle it makes use of the Burmister model. The various pavement properties enables the software to provide permissible parameters as well as determines the stresses and deflections of the structure thanks to the theoretical model chosen. The permissible stresses and deflections were obtained from the Alize software by inputting the results of the laboratory tests carried out, the traffic loadings, risk value involved and observational data from similar pavements.

For bituminous materials, the horizontal permissible tensile strain is given by the following formula:

$\varepsilon_{\mathrm{t}, \mathrm{perm}}=\varepsilon_{6}\left(\frac{\mathrm{NE}}{10^{6}}\right)^{\mathrm{b}} * \mathrm{~K}_{\mathrm{r}} \mathrm{K}_{\mathrm{c}} \mathrm{K}_{\mathrm{s}}$

with $\varepsilon_{6}$ : strain due to one million loads, E: Elasticity at a temperature of $10^{\circ} \mathrm{C}$, NE: Number of equivalent axles $=13 \mathrm{~T}$, b: slope of the fatigue line, $\mathrm{S}_{\mathrm{h}}$ : standard deviation on the thickness of the layer, $\mathrm{K}_{c}$ : Calibration coefficient, $\mathrm{K}_{\mathrm{S}}$ : Coefficient taking into account the heterogeneity of the bearing pressure of the support, r: risk, Kr: Risk

Table 3 The different classes of traffic (CEBTP, 1984)

\begin{tabular}{lll}
\hline Equivalent number of trucks & Traffic classes & $\begin{array}{l}\text { Equivalent number } \\
\text { of vehicles per day }\end{array}$ \\
\hline$<5 \times 10^{5}$ & T1 & $<300$ \\
From $5 \times 10^{5}$ to $1.5 \times 10^{6}$ & T2 & $300-1000$ \\
From $1.5 \times 10^{6}$ to $4 \times 10^{6}$ & T3 & $1000-3000$ \\
From $4 \times 10^{6}$ to $10^{7}$ & T4 & $3000-6000$ \\
From $10^{7}$ to $2 \times 10^{7}$ & T5 & $6000-12,000$ \\
\hline
\end{tabular}


Table 4 Parameters used to determine the allowable deflection of bituminous materials

\begin{tabular}{lllllllll}
\hline & $\varepsilon$ ( $\mu$ déf) & $\mathrm{E}(\mathrm{MPa})$ & $-1 / \mathrm{b}$ & $\mathrm{S}_{\mathrm{h}}(\mathrm{cm})$ & $\mathrm{S}_{\mathrm{N}}$ & $\mathrm{K}_{\mathrm{C}}$ & $\mathrm{r}(\%)$ & $\mathrm{K}_{\mathrm{S}}$ \\
\hline Bituminous materials & 100 & 7200 & 5 & 1 & 0.25 & 1.1 & 10 & 1 \\
\hline
\end{tabular}

Table 5 Parameters used for the determination of the permissible stress of stabilized materials

\begin{tabular}{llllllll}
\hline & $\sigma_{6}(\mathrm{MPa})$ & $-1 / \mathrm{b}$ & $\mathrm{S}_{\mathrm{h}}(\mathrm{cm})$ & $\mathrm{S}_{\mathrm{N}}$ & $\mathrm{K}_{\mathrm{c}}$ & $\mathrm{K}_{\mathrm{S}}$ & $\mathrm{K}_{\mathrm{d}}$ \\
\hline Stabilized materials & 0.75 & 15 & 0.03 & 1 & 1.4 & 1 \\
\hline
\end{tabular}

Table 6 Identification tests parameters for burrow pit materials

\begin{tabular}{llllllll}
\hline Samples (\%) & E1 & E2 & E3 & E4 & E5 & E6 & E7 \\
\hline Water content $\omega$ & 23.3 & 23.5 & 23.3 & 23.0 & 16.8 & 15.2 & 15.1 \\
Liquid limit LL & 64.0 & 77.0 & 64.0 & 69.0 & 61.0 & 56.0 & 52.0 \\
Plastic limit PL & 39.0 & 56.0 & 39.0 & 47.0 & 41.0 & 38.0 & 37.0 \\
Plasticity index PI & 25.0 & 21.0 & 25.0 & 22.0 & 20.0 & 18.0 & 15.0 \\
Percentage fines content & 30.0 & 25.0 & 11.0 & 15.0 & 12.0 & 10.0 & 10.0 \\
\hline
\end{tabular}

Table 7 Identification tests parameters for sub-grade materials

\begin{tabular}{llllllllll}
\hline Samples (\%) & B1 & B2 & B3 & B4 & B5 & B6 & B7 & B8 & B9 \\
\hline Water content $\omega$ & 15.2 & 23.9 & 24.8 & 27.3 & 27.1 & 29.5 & 44.9 & 15.9 & 23.9 \\
Liquid limit LL & 66.4 & 78.9 & 64.1 & 65.3 & 70.8 & 62.3 & 64.0 & 54.1 & 56.8 \\
Plastic limit PL & 39.1 & 43.5 & 44.1 & 35.2 & 51.6 & 32.6 & 36.4 & 28.5 & 32.3 \\
Plasticity index PI & 27.3 & 35.4 & 20.0 & 30.1 & 19.2 & 29.7 & 27.6 & 25.6 & 24.5 \\
Percentage fines content & 86.9 & 76.7 & 62.5 & 82.9 & 96.2 & 76.8 & 79.7 & 46.1 & 35.1 \\
\hline
\end{tabular}

coefficient, C: Coefficient linking the variation of deflection to the variation of the roadway, $\delta$ : Standard deviation thickness/fatigue.

The values utilized to determine the allowable deflection of bituminous materials is given in Table 4 .

For stabilized materials, the permissible horizontal tensile stress in bending is obtained by the relation.

$\sigma_{t, \text { perm }}=\sigma_{b}\left(\frac{N E}{10^{6}}\right)^{b} K_{r} K_{d} K_{c} K_{s}$

where all the other coefficient parameters are as given above and Kd: Coefficient of discontinuity for the base layer.

The values of the parameters used in the calculation of the allowable stress are given in the Table 5 .

For granular materials the (sub-grade soil, burrow), the permissible compressive vertical deformation is calculated by the following expression:

$\varepsilon_{\mathrm{z}, \text { perm }}=\mathrm{A}(\mathrm{NE})^{-0.22}$

where $\mathrm{NE}=$ Number of equivalent axels.

For medium and high traffic roads ( $\mathrm{T}>\mathrm{T} 3$ ): $\mathrm{A}=0.012$.
For low traffic roads $(T \leq T 3): A=0.016$.

\subsection{Presentation of the results}

The in situ investigations carried out on the burrow and the sub-grade materials show that the trial pits are characterized by various soil horizons separated by clear boundaries and each consisting of a layer of dark colored humus. The identification tests allowed us to determine the water content $(\omega)$, the percentage of fines, the liquid limit (LL), the plastic limit $(\mathrm{PL})$ and the plasticity index (PI) as shown in Tables 6 and 7. The mechanical characteristics tests (modified Proctor, CBR, and simple compression) which were performed on burrow materials gave optimum dry densities between 16 and $17 \mathrm{kN} / \mathrm{m}^{3}$, with the optimal water contents between 13.1 and $19 \%$. The results of the CBR shear tests moulded at $95 \%$ Modified Proctor gave CBR values between 32 and 49; the elastic modulus $\left(E_{d y n}\right)$ obtained from simple compression tests varies between 927 and $2295 \mathrm{MPa}$. Meanwhile for the sub-grade materials we obtained dry densities ranging from 14.1 to $18.9 \mathrm{kN} / \mathrm{m}^{3}$ with optimal water contents ranging from 11.7 to $29.7 \%$. The CBR moulded at $95 \%$ 
Table 8 CBR and the elastic modulus $\left(E_{\text {dyn }}\right)$ values of burrow material

\begin{tabular}{lrrrrrrr}
\hline Samples & E1 & E2 & \multicolumn{1}{c}{ E3 } & \multicolumn{1}{c}{ E4 } & E5 & \multicolumn{1}{c}{ E6 } & \multicolumn{1}{c}{ E7 } \\
\hline CBR & 32 & 36 & 38 & 40 & 43 & 47 & 49 \\
E $_{\text {dyn }}(\mathrm{MPa})$ & 927 & 999 & 1245 & 1299 & 1734 & 1842 & 2295 \\
\hline
\end{tabular}

Table 9 CBR and $E_{\text {dyn }}$ Values for sub-grade soils

\begin{tabular}{llllllllll}
\hline Samples & B1 & B2 & B3 & B4 & B5 & B6 & B7 & B8 & B9 \\
\hline CBR & 13.5 & 11.2 & 6.5 & 11.3 & 11.2 & 11.3 & 11.2 & 19 & 14.4 \\
E dyn $(\mathrm{MPa})$ & 186 & 144 & 111 & 156 & 144 & 156 & 144 & 249 & 219 \\
\hline
\end{tabular}

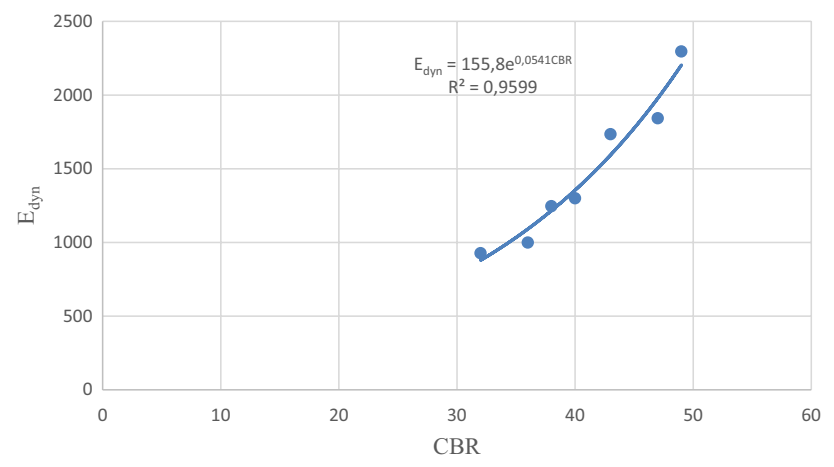

Fig. 5 Regression curve of the dynamic modulus of elasticity versus CBR (burrow pit)

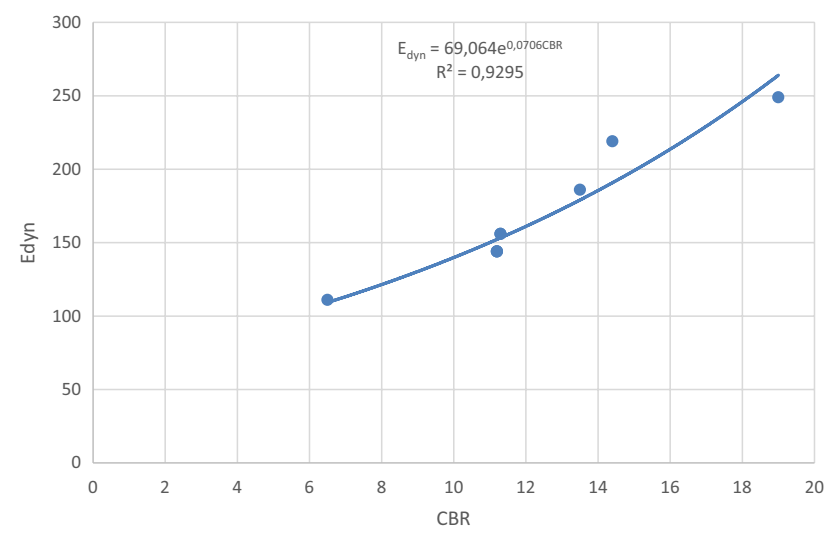

Fig. 6 Regression curve of the dynamic modulus of elasticity versus CBR (Sub-grade)

Modified Proctor ranged between 6.5 and 19, the elastic modulus $\left(\mathrm{E}_{\mathrm{dyn}}\right)$ obtained from simple compression tests varies between 111 and 249. These results are summarized in Tables 8 and 9.

From these data in Tables 8 and 9 we obtain the regression curves of the modulus of elasticity $\left(E_{d y n}\right)$ as a function of the CBR of both sub-grade and burrow materials as shown in Figs. 5 and 6.
Table 10 Proposed preliminary pavement structure with pavement material

\begin{tabular}{lcl}
\hline Pavement layers & $\begin{array}{l}\text { Thick- } \\
\text { ness }(\mathrm{cm})\end{array}$ & Nature of materials \\
\hline $\begin{array}{l}\text { Riding surface } \\
\text { Base }\end{array}$ & 5 & $\begin{array}{l}\text { Bituminous concrete } \\
\text { Lateritic gravel or natural gravel } \\
\text { stabilized with cement } \\
\text { Lateritic gravel or natural gravel 0/D }\end{array}$ \\
\hline
\end{tabular}

\subsection{Pavement design}

The determination of the constituents of the road layer and their characteristics (thickness, Young's modulus, etc.) must enable the highway to support the traffic loadings within the expected lifespan of the road. This is carried out either empirically or by a more rational method. The empirical approach consists of the CBR method as well as the semi-empirical approach, which takes into account the observation of existing pavements, and sometimes the mechanical behavioral patterns of materials. A more rational method utilizes principles of continuum mechanics and strength of materials.

\subsubsection{Material characteristics and traffic}

For the burrow pit and sub-grade materials, the respective design parameters utilized are ( $C B R=40.7$ and 12.2) modulus of elasticity $(E=1409 \mathrm{MPa}$ and $E=163 \mathrm{MPa})$ obtained from their respective regression equations as well as the Poisson ratio ( $\mu=0.25$ for stabilized materials and 0.35 for other materials i.e. bituminous materials and lateritic gravels). The rational dimensioning approach requires that stresses and deflections be determined by choosing a preliminary pavement structure comprising of its successive layers. With a cumulative traffic demand between $1.5 \times 10^{6}$ and $4 \times 10^{6}$ (depending on the vehicle count ratio) and an average sub-grade CBR of 12.2; we obtain a T3 traffic class and an S3 soil bearing class corresponding to a preliminary pavement structure shown on Table 10. Table 11 gives the choice of pavement materials and the corresponding 
Table 11 Choice of pavement materials and corresponding thicknesses with respect to road traffic loadings and subgrade thickness in centimeters. Source: Practical guide for pavement design for tropical countries T.2 BCEOM CEBTP

\begin{tabular}{|c|c|c|c|c|c|c|c|c|c|c|c|}
\hline \multirow{2}{*}{\multicolumn{2}{|c|}{ Trafic $\mathrm{T}_{3}-\mathrm{T}_{4}$}} & \multicolumn{2}{|l|}{$\mathrm{S}_{1}$} & \multicolumn{2}{|l|}{$\mathrm{S}_{2}$} & \multicolumn{2}{|l|}{$\mathrm{S}_{3}$} & \multicolumn{2}{|l|}{$\mathrm{S}_{4}$} & \multicolumn{2}{|l|}{$\mathrm{S}_{5}$} \\
\hline & & $\mathrm{T}_{3}$ & $\mathrm{~T}_{4}$ & $\mathrm{~T}_{3}$ & $\mathrm{~T}_{4}$ & $T_{3}$ & $\mathrm{~T}_{4}$ & $\mathrm{~T}_{3}$ & $\mathrm{~T}_{4}$ & $\mathrm{~T}_{3}$ & $\mathrm{~T}_{4}$ \\
\hline $\mathrm{R}$ & Bituminous concrete & 5 & * & 5 & * & 5 & * & 5 & * & 5 & * \\
\hline$B$ & Lateritic gravel & 20 & * & 20 & * & 20 & * & 20 & $*$ & 25 & * \\
\hline $\mathrm{F}$ & Lateritic gravel & 40 & $*$ & 30 & * & 20 & * & 15 & * & 0 & * \\
\hline $\mathrm{R}$ & Bituminous concrete & 5 & 7 & 5 & 7 & 5 & 7 & 5 & 7 & 5 & * \\
\hline B & $\begin{array}{l}\text { Lateritic gravel or crushed natural gravel } \\
\text { stabilized with cement }\end{array}$ & 20 & 20 & 20 & 20 & 20 & 20 & 20 & 20 & 20 & * \\
\hline $\mathrm{F}$ & Lateritic gravel or crushed natural gravel 0/D & 45 & 50 & 25 & 30 & 20 & 25 & 15 & 20 & 0 & * \\
\hline $\mathrm{R}$ & Bituminous concrete & 5 & 7 & 5 & 7 & 5 & 7 & 5 & 7 & 5 & 7 \\
\hline $\begin{array}{l}B \\
F\end{array}$ & Crushed aggregate $0 / d$ & 60 & 65 & 45 & 30 & 40 & 45 & 30 & 35 & 20 & 23 \\
\hline $\mathrm{R}$ & Bituminous concrete & 5 & * & 5 & * & 5 & * & 5 & * & 5 & * \\
\hline B & Sandy clay stabilized with cement & 20 & * & 20 & * & 20 & * & 20 & * & 20 & * \\
\hline $\mathrm{F}$ & Sandy clay & 55 & $*$ & 35 & * & 25 & * & 20 & * & 0 & * \\
\hline
\end{tabular}

R: riding surface, B: base layer, F: sub-base layer thicknesses with respect to road traffic demands and subgrade thickness in accordance with the CEBTP method.

\subsubsection{Determination of the allowable stresses}

The allowable limits corresponds either to stresses or to deflections of the sub-grade. Thus, for the wearing course (bituminous materials), the permissible horizontal flexural tensile strain $\varepsilon_{\mathrm{t} \text {, perm }}=62.8 \mu \mathrm{def}$; for the base layer (materials stabilized with hydraulic binders), we have the permissible horizontal stress $\sigma_{\mathrm{t} \text {, perm }}=0.427 \mathrm{MPa}$ and for the sub-base layer (lateritic gravel or granular materials) the permissible vertical deformation $\varepsilon_{z, \text { perm }}=487.3 \mu$ déf. In the Alizée software, the bending tensile stresses and their corresponding deformations are negative, the vertical displacements are positive and are in the direction of gravity and their positive values are considered. Thus, the values of these design parameters obtained from the Alize simulation for the designed pavement are given in Table 12. From Table 12, we have $\varepsilon_{\mathrm{t}}=-4.5 \mu$ def for the surface layer; $\sigma_{\mathrm{t}}=-0.118 \mathrm{MPa}$ (base layer); $\varepsilon_{\mathrm{z}}=103.8 \mu \mathrm{f}$ corresponding to the sub-base layer.
Table 12 Verification of pavement parameters from Alize software

\begin{tabular}{|c|c|c|c|c|}
\hline Level of Calculationono & Epsilon T horizontal & Sigma T horizontal & Epsilon Z Vertical & Sigma Z vertical \\
\hline \multicolumn{5}{|l|}{ Surface $(z=0.000)$} \\
\hline $\begin{array}{l}\mathrm{h}=0050 \mathrm{~m} 0.000 \mathrm{~m} \\
\mathrm{E}=7200.0 \mathrm{MPa}\end{array}$ & - 19.7 X-J & 0084 X-J & - 36.4 Z-J & $0658 \mathrm{Z}-\mathrm{R}$ \\
\hline $\begin{array}{l}\mu=03500.050 \mathrm{~m} \\
\text { Joined }(z=0.050 \mathrm{~m})\end{array}$ & $-14.5 \mathrm{Y}-\mathrm{R}$ & 0162 Y-R & $64.5 \mathrm{Z}-\mathrm{R}$ & 0583 Z-R \\
\hline $\begin{array}{l}\mathrm{h}=0200 \mathrm{~m} 0.050 \mathrm{~m} \\
\mathrm{E}=2300.0 \mathrm{MPa}\end{array}$ & $-14.5 \mathrm{Y}-\mathrm{R}$ & 0085 Y-J & 219.9 Z-R & 0583 Z-R \\
\hline $\begin{array}{l}\mu=02500.250 \mathrm{~m} \\
\text { Joined }(z=0,250 \mathrm{~m})\end{array}$ & $-57,1 \mathrm{Y}-\mathrm{J}$ & $-0118 Y-R$ & $75,1 \mathrm{Z}-\mathrm{R}$ & 0122 Z-R \\
\hline $\begin{array}{l}\mathrm{h}=0,20 \mathrm{~m} \mathrm{0,250 \textrm {m }} \\
\mathrm{E}=1409.0 \mathrm{MPa}\end{array}$ & $-57,1$ Y-J & $-0048 Y-J$ & $103,8 \mathrm{Z}-\mathrm{R}$ & 0122 Z-R \\
\hline $\begin{array}{l}\mu=03500,450 \mathrm{~m} \\
\text { Joined }(z=0,250 \mathrm{~m})\end{array}$ & $-85,0 Y-J$ & $-0154 Y-J$ & 93,8 Z-J & 0033 Z-J \\
\hline $\begin{array}{l}h \text { infinite } 0,450 \mathrm{~m} \\
E=163,0 \mathrm{MPa}\end{array}$ & $-85,0 Y-J$ & -0002 Y-J & 203,8 Z-J & 0033 Z-J \\
\hline$\mu=0350$ & & & & \\
\hline
\end{tabular}

Units: $\mathrm{m}, \mathrm{MN}$ and MPa; deflections in $\mu$ def

Notations: $\mathrm{X}=$ tranversal axis, $\mathrm{Y}=$ axe longitudinal axis, $\mathrm{Z}=$ vertical axis, $\mathrm{R}=$ vertical axis wheel, $\mathrm{J}=$ vertical between joints 
3.5.2.1 Results interpretation and discussion The subgrade materials (B1, B2, B3, B4, B5, B6, B7, B8 and B9) were described using the HRB criterion as A-7-5 soils based on their plasticity indices, the fine contents and group indices $(19 ; 20 ; 12 ; 20 ; 16 ; 20 ; 19 ; 14 ;$ and 15$)$. The A-7-5 materials are classified as fair to poor materials for roadworks. The Casagrande plasticity chart classifies them as inorganic clays of high plasticity. Meanwhile the lateritic (burrow) materials utilized for the sub-base (E1, E2, E3, E4, E5, E6 and E7), was classified as A-2 based on the HRB criterion with group indices between 0 and 6 which allows this material to fall under excellent to good materials for roadworks. In summary these soils can be described as compressible nodular silty sands.

The results of the CBR tests prepared at 95\% Modified Proctor compaction on burrow materials gave indices between 32 and 49, while for the sub-grade soil, the CBR was between 6.5 and 19. These values made it possible to classify the soils within the 55 bearing class for the burrow materials, also class S2 and S3 for sub-grade materials using the Liautaud [12] criterion. Since the CBR of sub-grade soils are all greater than 5 , it follows that the sub-grade soils do not need improvement. However to meet certain constructional exigencies the lateritic soils can be improved by mechanical stabilization using basalt gravels as given by Hyoumbi et al. [8]. It is interesting to note that though the study area is found in the Western Highlands of Cameroon, the CBR values obtained within the Mbu Barfochu area are lower than those obtained by Djuickouo [5], who obtained 98 for the lateritic gravels formed on the Maka basalts within Dschang. This low CBR values, could be attributed to the trachytic nature of bedrock, which is low in ferromagnesian elements. Concurrently, the geomorphology characterized by steep slopes within the study area could be the reason for the low level of induration of Mbu-Baforchu lateritic soils. Geotechnical literature is replete with information of correlation of CBR with other soil properties [21], [7], [22], [19], [23], [11] but very few current works give a correlation of CBR and elastic modulus E [18], [20], [3]. Therefore upon using the regression relation obtained between the $C B R$ indices and the elastic modulus, we obtain $\mathrm{E}=163$ bars (sub-grade material) and $E=1409$ bars (burrow material). Using the ALIZEE-LCPC software a simulation was carried out with inputs being the Poisson ratio and layer thickness. The results obtained were $\varepsilon_{\mathrm{t}}=-14.5 \mu \mathrm{def}, \varepsilon_{\mathrm{t} \text {, perm }}=62.8 \mu \mathrm{def}$ for the surface layer; $\sigma_{t}=-0.118 \mathrm{MPa}$ with $\sigma_{\mathrm{t} \text {, perm }}=0.427 \mathrm{MPa}$ representing the permissible value for the base layer and $\varepsilon_{\mathrm{z}}=103.8 \mu \mathrm{def}, \varepsilon_{\mathrm{z}, \text { perm }}=487.3 \mu \mathrm{def}$ for the sub-base layer. From these results, it is evident that the designed pavement structure presents good characteristics since all the calculated values are lower than the permissible values. In other words, the pavement structure will not undergo any structural distress within the design period i.e. (15 years). Though NOUROU-Dine [17] researched on recycled materials, he also obtained similar results where the parameters of the pavement layers were lower than the permissible values; with $\varepsilon_{\mathrm{t}}=10.8 \mu \mathrm{def} ; \sigma_{\mathrm{t}}=2.46$ bars and $\varepsilon_{\mathrm{z}}=226.8 \mu \mathrm{def}$ while the respective permissible stresses and deflections were $\varepsilon_{\mathrm{t} \text {, perm }}=146.7 \mu \mathrm{def} ; \sigma_{\mathrm{t} \text {, perm }}=4.43$ bars and $\varepsilon_{z, \text { perm }}=544 \mu$ def. The values of the allowable stresses and deflections are presented in the Alizée sheets in "Appendix" section.

3.5.2.2 Comparison between the CEBTP method and the Alizée LCPC software We note that the CEBTP method is based essentially on the thickness of the subgrade soil and the nature of the traffic loading in a bid to size the various layers without giving information on use after commissioning. On the other hand, the Alizée software takes into account the mechanical characteristics (modulus of elasticity, Poisson ratio) of burrow materials (laterite and crushed gravel) and sub-grade; then on the nature of the interfaces of the layers. By combining these parameters with those resulting from the CEBTP method (layer thicknesses), the Alizée LCPC software gives the stresses and the deflections that the pavement section may be subjected to with time. However, the most significant limitations of the Alizée software relates to assumptions taken into consideration when inputting the data. The pavement layers and the soil materials are assumed homogeneous, elastic and isotropic. The dynamic elastic moduli of the wearing courses are not clearly defined and it is that which the software assumes which are utilized for design.

\section{Conclusion}

The objective of this work was to characterize the lateritic materials and determine a correlation between the Californian bearing ratio (CBR) with the modulus of elasticity $\left(E_{d y n}\right)$ the around the Mbu-Baforchu area in a bid to dimension a second access highway to the city of Bamenda. The geotechnical characteristics of the lateritic subgrade with regards to the HRB criterion is A-7-5 soil with variable group indices between 12 and 20 . The A-7-5 materials were classified as fair to poor materials for roadworks. While the burrow material is A-2 with variable, group indices between 0 and 6 and were classified as excellent to good materials for roadworks. The strength characteristics gives maximum dry densities that are between 16 and $17 \mathrm{kN} / \mathrm{m}^{3}$ for the burrow material with optimal moisture contents of between 13.1 and $19 \%$. For the sub-grade material, the maximum dry densities are between 14.1 and $18.9 \mathrm{kN} / \mathrm{m}^{3}$ and optimal moisture 
contents between 11.7 and $29.7 \%$. The CBR prepared at 95\% Modified Proctor gave indices of 32 and 49 for the burrow materials while the sub-grade material had CBR's of between 6.5 and 19. Studies of correlations made it possible to evaluate the values of the elastic modulus with respect to the $C B R$ of the lateritic materials. A regression equation between the elastic modulus and $C B R$ for the burrow material gave $E_{d y n}=155.8 \exp (0.0541 C B R)$ with a regression coefficient of 0.9599 while that for the subgrade material was $\mathrm{E}_{\mathrm{dyn}}=69.064 \mathrm{exp}(0.0706 \mathrm{CBR})$ with a regression coefficient of 0.9295 . From these it was realized that the relation binding the modulus of elasticity to the CBR is not linear as the empirical relationships generally used in road design; these relationships do not always reflect reality. The pavement structure designed for consists of a bituminous cover of $5 \mathrm{~cm}$, a base course of $20 \mathrm{~cm}$ and a sub-base course of $20 \mathrm{~cm}$, which is capable of carrying a traffic loading of up to 3000 vehicles per day. The different simulations carried out with the ALIZE-LCPC software shows us that the choice of the Poisson ratio is as important as that of the modulus of elasticity. These simulations gave us values of the stresses and deflections lower than the permissible values. The values obtained were $\varepsilon_{\mathrm{t}}=-14.5 \mu \mathrm{def}, \varepsilon_{\mathrm{t}, \text { perm }}=62.8 \mu \mathrm{def}$ for the riding surface; $\sigma_{\mathrm{t}}=-0.118 \mathrm{MPa}$ with $\sigma_{\mathrm{t} \text {, perm }}=0.427 \mathrm{MPa}$ representing the permissible value for the base layer and $\varepsilon_{\mathrm{z}}=103.8 \mu \mathrm{def}$, $\varepsilon_{z \text {, perm }}=487.3 \mu \mathrm{def}$ for the sub-base layer; which reassures us that the pavement structure is durable. We recommend further research in this area so as to create a database of geotechnical characteristics of lateritic pavement materials at the national and sub-regional levels for a much more thoughtful and rigorous pavement design and management procedure.

Funding This project was funded personally by the authors.

Data availability The data used this current study are available from the corresponding author on upon request.

\section{Compliance with the ethical standards}

Conflict of interest The authors declare that there is no conflict of interest.

\section{Appendix}

Sheet 1: Allowable value calculation: bituminous materials traffic data:

- MJA (Annual daily average) $=218$ heavy duty vehicles/d/direction/lane.

- Geometric increase. $=6.00 \%$.
- Design period $=15.0$ years.

- Cumulated traffic NPL $=1,852,100$ PL.

- Deduced traffic data:

- Increase arith. $=7.88 \%$.

- Cumulative equivalent traffic NE:

- Coefficient $\mathrm{CAM}=0.80$.

- Cumulative traffic $\mathrm{NE}=1,481,700$ standard axles.

Material data:

- Epsilon $6=100.00 \mu$ def.

- Reverse slope $1 / \mathrm{b}=-5.00$.

- Temperature $\theta=25^{\circ} \mathrm{C}$.

- Module $\mathrm{E}\left(10^{\circ} \mathrm{C}\right)=7200 \mathrm{MPa}$.

- Module $\mathrm{E}($ TétaEq) $=7200 \mathrm{MPa}$.

- Asp bituminous struct. $=0.050 \mathrm{~m}$.

- Standard deviation $\mathrm{S}_{\mathrm{h}}=0.010 \mathrm{~m}$.

- Standard deviation $\mathrm{S}_{\mathrm{N}}=0.250$.

- Risk $=10.0 \%$.

- Coefficient $\mathrm{Kr}=0.8640$.

- Coefficient Ks=1.

- Coefficient $\mathrm{Kc}=1.1$

- Allowable EpsilonT = 62.8 $\mu$ Def.

Sheet 2. Calculation of permissible value: materials treated with hydraulic binderstraffic data:

- MJA (Annual daily average) $=218$ heavy duty vehicles/d/direction/lane.

- Geometrical increase. $=6.00 \%$.

- Design period $=15.0$ years.

- Cumulated traffic NPL =1,852,100 PL.

- deduced traffic data:

- Arithmetic increase. $=7.88 \%$.

- Cumulative equivalent traffic NE:

- Coefficient $C A M=1$.

- Cumulative traffic $\mathrm{NE}=1,481,700$ standard axles.

- material data:

- $\mathrm{SIGMA6}=0.750 \mu \mathrm{def}$.

- Inverse slope $1 / \mathrm{b}=-11.00$.

- TétaEq $=25^{\circ} \mathrm{C}$.

- module $\mathrm{E}\left(10^{\circ} \mathrm{C}\right)=2300 \mathrm{MPa}$.

- E module (TétaEq) $=2300 \mathrm{MPa}$.

- Asp bituminous struct. $=0.20 \mathrm{~m}$.

- Standard deviation $S_{h}=0.030 \mathrm{~m}$.

- Standard deviation $\mathrm{S}_{\mathrm{N}}=1$.

- Risk $=10.0 \%$.

- Coefficient $\mathrm{Kr}=0.8640$.

- Coefficient Ks=1.

- Coefficient $\mathrm{Kc}=1.4$

- Coefficient kd=1.

- Permissible SigmaT $=0.427 \mathrm{MPa}$. 
Sheet 3. Calculation of permissible value: material: soils (medium and heavy traffic)traffic data:

- MJA (Annual daily average) $=218$ heavy duty vehicles/d/direction/lane.

- Geometric increase. $=6.00 \%$.

- Calculation period $=15.0$ years.

- Cumulated traffic NPL=1,852,100 PL.

- Traffic data deduced.

- Arithmetic increase. $=7.88 \%$.

- Cumulative equivalent traffic NE:

- Coefficient CAM=1.00.

- Cumulative traffic NE =1,852,100 standard axles.

- Material data:

- Coefficient $A=12,000$.

- Exponent $=-0.2220$.

- Allowable EpsilonZ=487.30 $\mu$ def.

\section{References}

1. Amawa SG, Jude Ndzifon K, Tata ES, Azieh EA (2015) The implications of climate variability on market gardening in Santa Subdivision. Canadian Center of Science and Education, North West Region of Cameroon, $\mathrm{p} 23$

2. Amadi AA, Sadiku S, Abdullahi M, Danyaya HA (2018) Case study of construction quality control monitoring and strength evaluation of a lateritic pavement using the dynamic cone penetrometer. Int J Pavement Res Technol 11(5):530-539

3. AASHTO (2003) Guidelines for pavement design. Virginia DoTMaterials Division Pavement Design and Evaluation

4. CEBTP (1984) Guide pratique de dimensionnement des chaussées pour les pays tropicaux. Ministre des relations Extérieur, de la coopération et du développement, $157 \mathrm{p}$

5. Djuickouo C.N., 2012. Caractérisation géotechnique des graveleux sur basaltes latéritiques de la zone de Maka (Dschang, Ouest-Cameroun). Mem. D.I.P.E.S II. ENS. Univ. Yaoundé I. 51p

6. Gountié DM, Njonfang E, Nono A, Kamgang P, Zangmo TG, Kagou DA, Nkouathio DG (2012) Dynamic evolution of mounts Bamboutos and Bamenda by study ignimbritic deposits (West-Cameroon Cameroon Line) syllabus review. Sci Ser 3(2012):11-23

7. Gregory GH, Cross SA (2007) Correlation of California bearing ratio with shear strength parameters. Transp Res Rec 1989(1):148-153

8. Hyoumbi WT, Pizette P, Ludovic AS, Razafimahatratra FN, \& Guouillier T. (2018) Influence des granulats basaltiques 0/5 sur les propriétés géotechniques des sols fins latéritiques de Bafang (Ouest-Cameroun) en vue de leur valorisation en technique routière. Journées Nationales de Géotechnique et de Géologie de l'Ingénieur - Champs-sur-Marne

9. Institut Géographique National - Paris, 1973. Carte de l'Afrique Centrale A 1/50000 (Type Outre-mer), Bafoussam 3c (Foumban - Dschang), République fédérale du Cameroun_Feuille NB -XI-3c

10. Kamgang P, Njonfang E, Nono A, Dedzo MG, Tchoua FM (2010) Petrogenesis of a silicic magma system: geochemical evidence from Bamenda Mountains, NW Cameroon, Cameroon volcanic line. J Afr Earth Sc 58(2):285-304

11. Katte VY, Mfoyet SM, Manefouet B, Wouatong ASL, Bezeng LA (2019) Correlation of California bearing ratio (CBR) value with soil properties of road subgrade soil. Geotech Geol Eng 37(1):217-234

12. Liautaud $G$ (1984) Guide pratique de dimensionnement des chaussées pour les pays tropicaux. CEBTP, $156 \mathrm{p}$

13. NF P 94-078 (1994) Indice CBR après immersion - Indice portant immédiat. Mesure sur échantillon compacté dans le moule CBR

14. NF P 94-051, 1993. Détermination des limites d'Atterberg. Limite de liquidité à la coupelle. Limite de plasticité au rouleau

15. NF P 94-056 (1996) Analyse granulométrique. Méthode par tamisage à sec après lavage

16. NF P 94-093 Détermination des caractéristiques de compactage d'un sol. Essai Proctor normal-Essai Proctor modifié

17. NOUROU-Dine IMAM (2003) Problématique du choix du module des matériaux recyclés dans le dimensionnement par la méthode rationnelle: application au tronçon Dimniado-Mbour

18. Ola SA (1980) Relationship Between CBR and Static Modulus of Deformation of Stabilized Stabilized Lateritic Soils. In: Seventh regional conference for Africa on soil mechanics and foundation engineering, Accra, pp 223-232

19. Patel RS, Desai MD (2010) CBR predicted by index properties for alluvial soils of South Gujarat. In: Proceedings of the Indian geotechnical conference, Mumbai, pp 79-82

20. Powell WD, Potter JF, Mayhew HC, Nunn ME (1984) The structural design of bituminous roads. No. LR 1132 monograph

21. Satyanarayana Reddy CNV, Pavani K (2006) Mechanically stabilised soils-regression equation for CBR evaluation. In: Proceedings of the Indian geotechnical conference, Chennai, India, pp 731-734

22. Vinod P, Reena C (2008) Prediction of CBR value of lateritic soils using liquid limit and gradation characteristics data. Highway Res J IRC 1(1):89-98

23. Yildirim B, Gunaydin O (2011) Estimation of California bearing ratio by using soft computing systems. Expert Syst Appl 38(5):6381-6391

Publisher's Note Springer Nature remains neutral with regard to jurisdictional claims in published maps and institutional affiliations. 